\title{
Perception of Tourist Guide to Gorontalo Tourism Destination
}

\author{
Srilian Laxmiwaty Dai ${ }^{1}$, Sri Sunarti ${ }^{1}$, Desrika Talib ${ }^{1}$, Anggraeni M. S. Lagalo ${ }^{1}$ \\ lyanlaxmiwaty@umgo.ac.id \\ ${ }^{1}$ Tourism Study Program, Muhammadiyah University of Gorontalo, Indonesia \\ Received: January 3, 2021 \\ Revised: January 15, 2021 \\ Accepted: January 28, 2021
}

\begin{abstract}
This study discusses tourists gude overview regarding the destination of tourism place in Gorontalo. This sort of inquire about is quantitative. Information collection strategies in this consider incorporate perception, this strategy is done by watching all exercises at the inquire about locationThe results shows that in terms of openness, Gorontalo has met the standard of accessibility of get to for sightseers to enter and exit Gorontalo as well as most of the get to to different visitor attractions in Gorontalo Tourism Goals. It is fundamental to extend the quality of human assets within the tourism division in Gorontalo. An appraisal of the uniqueness of Gorontalo culture which is considered exceptionally great may be a reality that happens in each locale in Indonesia since Indonesia is wealthy in social differing qualities which of course has its possess uniqueness.
\end{abstract}

Keywords: Gorontalo Tourism Goals, Tourists \& Quality

\section{Introduction}

Gorontalo is a province located in the northern part of Sulawesi Island. Like most regions, Gorontalo is also motivated to develop its tourism sector. Many efforts have been made in order to advance Gorontalo Tourism Destinations, one of which is by opening various kinds of tourist attractions. In addition, Gorontalo has the advantage of being geographically located close to Togean Island, Tehngah Sulawesi which attracts many tourists, especially foreign tourists who are often seen crowding the Gorontalo Ferry port. The luck of Gorontalo geographically invites tourists traveling to Togean Island to enter and leave Gorontalo because Gorontalo has been the gateway to Togean Island for tourists via Gorontalo Ferry Port. So that Gorontalo is called a transit city for tourists aiming at Togean Island.

Tourists aiming to Togean Island are dominated by foreign tourists entering Gorontalo Province via land and air transportation, then they continue their journey to Togean Island by ferry or sea transportation. Furthermore, from Togean Island, tourists use a Ferry to Gorontalo and leave Gorontalo by land and air transportation.

When making a transit, sometimes tourists have to stay overnight in Gorontalo because the ship does not operate every day and have to wait for the ship to arrive from Togean Island and then carry more passengers from Gorontalo to Togean Island. Foreign tourists transiting in Gorontalo spend about three days waiting for the ship's scheduled departure. During that time, they stayed at several hotels and small inns that are located close to the Gorontalo Ferry port. As for the number of foreign tourists based on manifest at the port, annually reaches approximately 600 to 700 foreign tourists. 
While waiting for the ferry departure schedule, there are tourists who spend their time independently without the help of tour guides. They enjoy the atmosphere of Gorontalo city around the inn where they live. However, there are also those who use tour guide services while in Gorontalo until they leave for Togean Island. It is not uncommon for tourists to ask their tour guides to accompany them to Togean Island. Therefore, many Gorontalo tour guides carry out tasks over land to the Central Sulawesi region. This is not a problem because tour guides have a national permit where their organization, the Indonesian Tour Guides Association (HPI), is a national guide organization under the auspices of the Ministry of Tourism and Creative Economy.

The fact that Gorontalo is a transit city has a great opportunity to become a major destination for tourists such as Togean Island or tourists who were only transiting can be used as a target market for Gorontalo Tourism Destinations so that they can spend more money in Gorontalo, stay longer in Gorontalo and enjoy the treats of tourist attractions in Gorontalo. If this happens, an ideal economic cycle will be created for the people of Gorontalo.

Realizing this, the Provincial Government of Gorontalo has made various efforts to take advantage of the opportunities above. The government and the people of Gorontalo wish to make Gorontalo a tourist destination that should be enjoyed. Various efforts have been made to develop the tourism industry. These efforts include improving various public facilities, increasing accessibility development, improving facilities at tourist attractions and adding tourist attractions in all regencies/cities and many other things that the government and tourism stakeholders do.

However, until now most of the transit tourists did not increase their expenses and time of stay in Gorontalo. Even though currently Gorontalo Tourism Destination has offered a variety of choices of tourist attractions along with various developments in terms of accessibility, amenities and the development of new tourist attractions. This fact is a dilemma for tourism stakeholders who think that the opportunity for Gorontalo as a transit city cannot be wasted.

The spirit of Gorontalo, which is excited in building tourist destinations, needs to be maintained and maintained. If development efforts have been made but are still unsuccessful, other effective methods are needed. For this reason, it is necessary to conduct a study on "Perceptions of Tour Guides on Gorontalo Tourism Destinations". The perception of foreign tourist guides transiting in Gorontalo regarding Gorontalo Tourism Destinations is considered very crucial because they interact directly with tourists, communicating intensively in a relatively long time between two or three days to seven or ten days in general. So it is highly believed that tour guides are people who really understand the character and tastes of tourists. They also often become a place for tourists to complain about shortcomings, give constructive suggestions as well as give praise and show admiration for the beautiful and interesting things in Gorontalo. From the experiences of tour guides, a perception is formed about Gorontalo Tourism Destinations which should be explored and described in order to achieve the goal of developing Gorontalo Tourism. Perception is a view that results from sensing either positively or negatively based on a situation that has been felt by the five human senses (Ingold, 1992; Sekuler, 1996; Lewkowicz, 2000; Kusherdyana, 2019). Knowing the perceptions of tour guides will greatly help the government and other tourism stakeholders to be taken into consideration in developing destinations and taking advantage of opportunities for Gorontalo as a transit city. 


\section{Related Studies}

There are several studies related to this research. The first research is about the Perception of Tourists on Product Innovation "Utama Spice Natural Aromatherapy" by Kembang at al. (2017). This research is considered relevant because it focuses on the perceptions or impressions of tourists who are the target market for a tourism product. The results of this study are a positive perception by tourists of these products so that it can be ascertained that these local products are accepted by consumers, both local people and tourists. For tourists, this product is very attractive because it uses traditional ingredients. This effort is increasingly expanding the Bali tourism industry which has a positive impact on the community's economy (Kembang et al., 2017). Another related research is the Perception of Visitors to the Nusa Pelangi Dairy Cattle Agro-tourism in Malang Regency, the result of this research is good visitor perception. This is evidenced by the visitor's assessment of comfort and impression, friendliness, use of facilities, and access and linkage classified as high (Ridwan et al., 2018). Next is a research on the Potential and Perceptions of Community and Tourists on Ecotourism Development in Aik Berik Village, Central Lombok by Murianto (2014). This research has negative and positive results. Most of the tourists who visit are not satisfied because the construction of facilities and infrastructure in Air Berik Village is still inadequate, but the potential that the village has such as panoramic views of rice fields, panoramic plantations, rivers, yarn Stokel waterfalls, thread netting waterfalls, and Kelewon waterfalls are very good for become an ecotourism attraction (Murianto, 2014).

The first two studies above aim to measure the extent to which tourists are attracted to tourist attractions. This study is different from this study because this study aims to identify the tastes of tourists who transit in Gorontalo through the perceptions of tour guides. From this, the answers will be obtained why transit tourists are reluctant to make Gorontalo their main destination or make them want to stay longer in Gorontalo and not just wait for the schedule of ships to or arrive from Togean Island. The last research, which is in Air Berik Village, this research is the same as research on the perceptions of tour guides on Gorontalo Tourism Destinations. This study identifies factors of dissatisfaction or disinterest in tourists through foreign tour guides who generally transit in Gorontalo.

\section{Theoretical Basis}

\section{Perception}

The tour guide's perception regarding the satisfaction and taste of the consumers' tourism, in this case, tourists of good and satisfying tourist attractions and services will increase loyalty. The loyalty of consumers or tourists is priceless. If existing travelers can be loyal, this will guarantee new travelers will be attracted. Relatively large visits consist of old tourists who want to visit again because they have loyalty and new tourists who are interested in gaining experiences based on the positive information they get. (Irianto, 2011) states that positive perceptions are formed based on the maximum quality of service provided where the service meets the requirements of tourists' needs. With this explanation, it can be concluded that the importance of perceptions or thoughts of tour guides in developing a destination where good perceptions will be formed according to the experience of the guided tourists then give reactions and responses that describe their satisfaction or dissatisfaction while in the destination.

\section{Tourist}

Regulation of the Minister of Tourism Number 10 of 2009 states that the definition of tourism is "a travel activity carried out by a person or group of people by visiting certain

Copyright @ 2021, Journal of Asian Multicultural Research for Economy and Management Study, Under the license CC BY-SA 4.0 
places for recreational purposes, personal development, or learning the uniqueness of tourist attractions visited in a temporary period". Meanwhile, "tourists are people who do the tour". Tourists are said to be people who have interests and have an important role in managing tourist destinations (Maharani, 2018). Another definition of tourists is people who travel and move from their place of residence to other places and make interactions (Tambunan, 2009).

\section{Tourism Destinations}

Based on the Law of the Republic of Indonesia No. 10 of 2009 concerning Tourism, "tourist destination areas hereinafter referred to as Tourism Destinations are geographic areas located in one or more administrative areas in which there are tourist attractions, public facilities, tourism facilities, accessibility and communities that are interrelated and complement the realization of tourism. Pitana \& Diarta (2009) express their views on tourist destinations, namely an area in which there are all kinds of tourism activities with various stakeholders which result in the development of the tourism industry. Thus it can be concluded that a tourism destination is a geographical area in which there are tourism products in the form of goods and services that are developing as a tourism industry.

\section{Methods}

The research design of Transit Tourist Guides' Perceptions of Gorontalo Tourism Destinations has two problem formulations, namely; How is the perception of transit tourist guides on Gorontalo Tourism Destinations? and how are the efforts to develop Gorontalo Tourism Destinations? This type of research is quantitative.

\section{Data Collection Technique}

Data collection techniques in this study include observation, this technique is done by observing all activities at the research location. Distribution of questionnaires, this is done to 30 transit tourist guides who are members of the Indonesian Tour Guide Association in Gorontalo and the Gorontalo Tour Guide. Documentation, retrieval of data in document form. Data can be in the form of archives, pictures, graphics, brochures or books. All data obtained will be documented either in hard copy or in soft copy (Sugiyono, 2009).

\section{Data Analysis}

The data analysis technique used in this study consists of two techniques, the first is quantitative descriptive. This technique is an attempt to describe in detail the data that has been processed to obtain a solution that can answer the problem formulation. The second technique is the Likert scale where according to Kusmayadi (2000) the Likert scale can measure the perceptions and attitudes of respondents ranging from very positive thinkers to very negative thoughts with the following formulations:

Interval $=\mathrm{R}$

\section{$\mathrm{K}$}

Information: $\mathrm{R}=$ the highest score

$\mathrm{K}=$ Total Rating Scale

\section{Results and Discussion}

To find out the views or perceptions of foreign tourists about Gorontalo as a destination, this can be done indirectly by distributing questionnaires to foreign tourist guides as well as interviewing them. Making foreign tourist guides as respondents as well as informants on the basis of their experience guiding foreign tourists and of course an intense conversation occurs 
so that they are very familiar with the perceptions of foreign tourists towards Gorontalo in general.

Table 1. Questionnaire Data on Perceptions of Foreign Tourist Guides (Transit) on Gorontalo Tourism Destinations

\begin{tabular}{|l|c|c|c|c|c|}
\hline \multirow{2}{*}{ Tourist Guide Perception } & \multicolumn{5}{|c|}{ Number of Foreign Tourist Guide } \\
\cline { 2 - 6 } & $\begin{array}{c}\text { Value } \\
\text { Weight 5 }\end{array}$ & $\begin{array}{c}\text { Value } \\
\text { Weight 4 }\end{array}$ & $\begin{array}{c}\text { Value } \\
\text { Weight 3 }\end{array}$ & $\begin{array}{c}\text { Value } \\
\text { Weight 2 }\end{array}$ & $\begin{array}{c}\text { Value } \\
\text { Weight 1 }\end{array}$ \\
\hline $\begin{array}{l}\text { Gorontalo Tourist Destination } \\
\text { Accessibility }\end{array}$ & 8 & 19 & 3 & 0 & 0 \\
\hline $\begin{array}{l}\text { Gorontalo Tourist Destination } \\
\text { Atraction }\end{array}$ & 0 & 6 & 14 & 10 & 0 \\
\hline $\begin{array}{l}\text { Amenities of Gorontalo } \\
\text { Tourism Attractions }\end{array}$ & 0 & 2 & 13 & 15 & 0 \\
\hline $\begin{array}{l}\text { Gorontalo Natural Resources } \\
\text { Human Resources in } \\
\text { Gorontalo }\end{array}$ & 0 & 5 & 0 & 0 & 0 \\
\hline $\begin{array}{l}\text { Gorontalo Cultural Uniqueness } \\
\text { Gorontalo potentiality as } \\
\text { leading destination }\end{array}$ & 30 & 0 & 20 & 8 & 0 \\
\hline
\end{tabular}

Source: Research Results 2020

\section{Accessibility of Gorontalo Destinations}

Based on table 1 above, in the first indicator, there are eight tour guides (26\%) who think that the accessibility of Gorontalo Tourism Destinations is very good. Meanwhile, most of the tour guides, namely nineteen people $(63 \%)$, considered that the accessibility of Gorontalo Tourism Destinations was good and there were three tour guides $(10 \%)$ who were sufficient. Meanwhile, regarding the accessibility, no one considered it less or bad. The attitude scale obtained was 125 with an average value of 4.1. Overall the results on the first indicator show that the assessment of the accessibility of Gorontalo Tourism Destinations is considered good.

\section{Attractions in Gorontalo Tourism Destinations}

Based on the table above, there is no single tour guide who thinks that the tourist attractions in Gorontalo Tourism Destinations are very good. Furthermore, there are six tour guides (20\%) who think that the tourist attractions in Gorontalo Tourism Destinations are good. Meanwhile, fourteen people $(46 \%)$ think that the tourist attractions in Gorontalo Tourism Destinations are quite good. Then there are ten tour guides (33\%) who think that the attractions in Gorontalo Tourism Destinations are not good. Even so, none of them think that the attractions in Gorontalo Tourism Destinations are bad. The attitude scale obtained was 86 with an average value of 2.8. Overall the results on the second indicator show that the assessment of the attractions in Gorontalo Tourism Destinations is considered quite good.

\section{Amenities tourist attraction in Gorontalo}

Based on the table above, there is no tour guide who is of the opinion that the amenities in tourist attractions in Gorontalo as a whole are very good. However, two tour guides (7\%) rated it as well. Meanwhile, there were thirteen tour guides $(43 \%)$ who rated it quite well. Then there were also fifteen tour guides $(50 \%)$ who rated poor and no one rated bad. The

Copyright (C) 2021, Journal of Asian Multicultural Research for Economy and Management Study, 
attitude scale obtained was 77 with an average value of 2.5 . Overall the results on the third indicator indicate that the assessment of the amenities is attractive. The tourist attraction in Gorontalo is still not good.

\section{Gorontalo Natural Resources}

Based on the table above, there are twenty-five tour guides (83\%) who have the same viewpoint that the natural resources in Gorontalo are very good. Furthermore, there were five tour guides $(17 \%)$ who rated it as well, while no one rated it as good, bad, or bad. The attitude scale obtained was 145 with an average value of 4.8. Overall the results on the fourth indicator show that the assessment of Gorontalo natural resources is very good.

\section{Human Resources in Gorontalo}

Based on the table above, there is no tour guide who thinks that the human resources in Gorontalo are very good. Then only two tour guides $(7 \%)$ rated it good. Furthermore, there were twenty people (67\%) who rated it as good enough and there were eight people $(26 \%)$ who considered it not good. Meanwhile, there is no one who thinks badly. So the attitude scale obtained is 84 with an average value of 2.8. Overall, the results on the fifth indicator indicate that the assessment of human resources in Gorontalo is quite good.

\section{The uniqueness of Gorontalo Culture}

Based on the table above, there are thirty tour guides (100\%) who think that Gorontalo culture is very good. Meanwhile, there were none who rated good, good enough, not good and bad. So the attitude scale obtained is 150 with an average value of 5. Overall the results on the sixth indicator show that the assessment of the uniqueness of Gorontalo culture is very good.

\section{Gorontalo Potential as a Leading Destination}

Based on the table above, there are thirty tour guides (100\%) who think that the potential of Gorontalo as a leading destination is very good. Meanwhile, there were none who rated good, good enough, not good and bad. So the attitude scale obtained is 150 with an average value of 5 . Overall the results on the seventh indicator show that the assessment of the tourism potential of Gorontalo is very good.

In general, the results of the questionnaires that have been distributed can be concluded that in terms of accessibility, Gorontalo has met the standard of availability of access for tourists to enter and exit Gorontalo as well as most of the access to various tourist attractions in Gorontalo Tourism Destinations. Meanwhile, tourist attractions in Gorontalo Tourism Destinations are considered quite good. This assessment does not necessarily satisfy stakeholders because there needs to be an increase so that it can become a leading tourist attraction and attract foreign tourists and can change Gorontalo's status as a transit area to become a destination for foreign tourists. Furthermore, regarding the availability of amenities at tourist attractions in Gorontalo Tourism Destinations, it is considered not good because there are still many obstacles that are found for both tourists and foreign tourist guides. This is inversely proportional to the assessment of natural resources in Gorontalo which is rated as very good because basically natural resources have been created so beautifully. Indonesia is a country located between the Asian Continent and the Australian Continent which has various natural resources that are supported by a tropical climate so as to produce unique animal and plant species (Kusmayadi, 2000). Like other areas in Indonesia Gorontalo also has a natural beauty that is no less amazing and can be used as a tourist attraction with environmentally based and sustainable management. Good

Copyright $\odot$ 2021, Journal of Asian Multicultural Research for Economy and Management Study, 
management is needed so that the assessment on the second indicator can be improved. Furthermore, an assessment of natural resources does not appear to be comparable with an assessment of human resources which is considered insufficient. In Gorontalo itself, there are indeed many human resources who have received an education, especially in the tourism sector, but when compared to the number of Gorontalo residents, which reached 1,202,631 people in 2019, it is considered very lacking. So it is necessary to increase the quality of human resources in the tourism sector in Gorontalo. Furthermore, an assessment of the uniqueness of Gorontalo culture which is considered very good is a fact that occurs in every region in Indonesia because Indonesia is rich in cultural diversity which of course has its own uniqueness. Assessment of the potential of Gorontalo as a leading destination is considered to be very good, this happens because at the point of natural resources and cultural uniqueness it is considered very good so that these two things become the potential strength of Gorontalo to become a leading tourist attraction.

\section{Conclusion}

Great administration is required so that the appraisal on the moment marker can be moved forward. Moreover, an evaluation of characteristic assets does not show up to be comparable with an appraisal of human assets which is considered deficiently. In Gorontalo itself, there are undoubtedly numerous human assets who have gotten an instruction, particularly within the tourism division, but when compared to the number of Gorontalo inhabitants, which come to $1,202,631$ individuals in 2019 , it is considered exceptionally missing. So it is essential to extend the quality of human assets within the tourism segment in Gorontalo.

\section{References}

Irianto. (2011). Dampak Pariwisata Terhadap Kehidupan Sosial dan Ekonomi Masyarakat di Gili Trawangan Kecamatan Pemenang, Kabupaten Lombok Utara. Jurnal Bisnis dan Kewirausahaan, 7(3), 188-194.

Kembang, N. P. A., Ardika, I. W., \& Dewi, M. H. U. (2017). Persepsi Wisatawan Terhadap Inovasi Produk "Utama Spice Natural Aromaterapi". Jurnal Master Pariwisata (JUMPA), 3(2), 313-322.

Kusherdyana, M. P. (2019). Pemahaman Lintas Budaya: dalam Konteks Pariwisata Dan Hospitalitas. Alfa Beta.

Kusmayadi, E. S. (2000). Metodologi penelitian dalam bidang kepariwisataan. Jakarta: Gramedia Pustaka Utama.

Lewkowicz, D. J. (2000). The development of intersensory temporal perception: an epigenetic systems/limitations view. Psychological bulletin, 126(2), 281.

Maharani, P. A. M., Putra, I. N. D., \& Paturusi, S. A. (2018). Persepsi Wisatawan Asing Terhadap Pelayanan Kesehatan Di Bali: Studi Kasus Rumah Sakit Balimèd. Jurnal Master Pariwisata (JUMPA), 4(2), 310-326.

Murianto, M. (2014). Potensi dan Persepsi Masyarakat Serta Wisatawan Terhadap Pengembangan Ekowisata di Desa Aik Berik, Lombok Tengah. Jurnal Master Pariwisata (JUMPA), 1(1) 43-64.

Pitana, I. G., \& Diarta, I. K. S. (2009). Pengantar Ilmu Pariwisata. Yogyakarta. 
Ridwan, A., Azizah, S., \& Kusumastuti, A. E. (2018). Persepsi Pengunjung Terhadap Agrowisata Sapi Perah Nusa Pelangi Di Kabupaten Malang. Jurnal Master Pariwisata (JUMPA), 5(1), 57-76.

Sekuler, R. (1996). Motion perception: A modern view of Wertheimer's 1912 monograph. Perception, 25(10), 1243-1258.Ingold, T. (1992). Culture and the perception of the environment. Bush base: forest farm. Culture, environment and development, 39-56.

Sugiyono, (2009). Metode Penelitian Bisnis, Bandung: Alfabeta

Tambunan, N. (2009). Posisi transportasi dalam pariwisata. Majalah Ilmiah Panorama Nusantara, 4(1-6), 39-48. 